\title{
Iraqi Geological Journal
}

\author{
Journal homepage: https://www.igj-iraq.org
}

\section{Discharge Measurement for a Part of Lesser Zab River by Using Georadar and Current Meter at Klesa of Erbil, NE Iraq}

\author{
Galawezh B. Bapeer ${ }^{1, *}$, Hawkar B. Bakir ${ }^{2}$, Anwer Dawood ${ }^{1}$, Nadhir Al- Ansari ${ }^{3}$ and Bahra D. Ghafur ${ }^{1}$ \\ Geotechnical Engineering Department, Faculty of Engineering, Koya University, Koya, KOY45, Kurdistan Region, Iraq \\ Petroleum Engineering Department, Faculty of Engineering, Koya University, Koya, KOY45, Kurdistan Region, Iraq \\ Lulea University of Technology, Lulea, 971 87, Sweden \\ Correspondence: galawezh.bakr@koyauniversity.org
}

\begin{abstract}
Received:

14 July 2021

A Ground Penetrating Radar for bathymetry and water current velocity was used to estimate

Accepted:

3 December 2021 the discharge value of Lesser Zab River at Klesa station with coordinates ( $35^{\circ} 53^{\prime} 08.21^{\prime \prime} \mathrm{N}$, $\left.44^{\circ} 35^{\prime} 35.90^{\prime \prime} \mathrm{E}\right)$. Two traverses were taken across the river which represented two sites in Klesa area which were (A-B) traverse with the coordinates (N 3970652 and E 491898), and (C-D) traverse with the coordinates (N 3972195 and E 487681). Measuring water flow rate

Published: by velocity area method was done by Mid-section method, to confirm the validity of the

28 February 2022 data; two sections were conducted for each of the two traverses to deduce two radargrams along the profiles (A-B) and (D-C). The radargrams drew by using sophisticated software and were very helpful in detecting the river floor topography and depth variation along both profiles, the distance between the two sites was $5 \mathrm{~km}$. The results indicate that the maximum width of the river at stations is $36.5 \mathrm{~m}$ and the maximum water depth of Lesser Zab River is $4.75 \mathrm{~m}$, maximum velocity is $1.88 \mathrm{~m} / \mathrm{s}$. The water flow rate deviates from $136.737 \mathrm{~m}^{3} / \mathrm{s}$ to $147.23 \mathrm{~m}^{3} / \mathrm{s}$. The average discharge for Lesser Zab river $=141.983 \mathrm{~m}^{3} / \mathrm{s}$. This discharge is under normal average because the data was taken in November 2019. Because of the mild weather and the lack of electricity consumption, so using these results in water resource management and planning for satisfying domestic consumption, irrigation, industrial consumption, ...etc. in the Klesa area, will be economically beneficial for the water management policy of the country
\end{abstract}

Keywords: River bathymetry; Georadar equipment; Current meter; Flow rate measurement; Mid-section method

\section{Introduction}

Lesser-Zab is one of five tributaries of the river Tigris and the main river draining through the Sulaimaniyh province (Kassim et al., 2007). Approximately 76\% of the Lesser-Zab watershed area is situated within Iraqi border while the remaining lies on the Iranian border. (Aziz et al., 2017). Overtime, rivers respond to changes in the environment through erosion and sedimentation processes, or by the direct influence of the human role (Sadeq and Alhamdany, 2021). Discharge measurement is of prime importance for management and distribution of water resources. All the design work and channel layout plans are governing by this data (Chauhan et al., 2014). Discharge measurements in natural watercourses are performed in order to determine the value of the surface outflow of a basin (Tazioli, 2011). Flow

DOI: 10.46717/igj.55.1B.5Ms-2022-02-21 
information is necessary in many diverse applications including water supply management, pollution control, irrigation, flood control, energy generation, and industrial use (Harpold, 2006). The most commonly used instrument in hydrometry to measure the velocity at a point in the flow cross section is the current meter (Subramanya, 2008). The main velocity is taken as that at 0.6 -meter depth below water surface in shallow water, and at $0.2 \mathrm{~m}$ depths and $0.8 \mathrm{~m}$ depths below the water surface deep water (Raghunath, 2006). River flow forecasting is a very important issue, when the river flows are stored in artificial reservoirs, the inflows forecasting allows to plan and adequately support the decision making for multipurpose reservoir releases (Termite et al., 2013).

Ground Penetrating Radar (GPR) uses electromagnetic reflection method, and it is one of the nondestructive testing (NDT) techniques that can image at subsurface depth in high resolution. (Amran et al., 2017). Common- offset reflection (COR) is a widely used GPR surveying mode for bathymetry. A device with fixed antenna configuration is dragging along profiles to map reflections versus position (Bapeer and Bakir, 2018). Simultaneous bathymetric and sub-bottom surveying using GPR techniques can rapidly reveal sediment thickness without referring to previously known topography (Lachhab et al., 2015). The image of GPR survey is thus largely determined by the variation in dielectric properties of the subsurface (Bakir and Thabit, 2016). The GPR system scans the ground to collect the data at various locations (David et al., 1997). Scans are traces where a color or gray scale have been used to the amplitude values, while the antennas are dragged along a survey line, a series of traces or scans are collected at discrete points along the line, (Daniels, 1998). The power of the radar transmitter, the sensitivity of the receiver and numerical signal processing of the acquired data are also important considerations (Cunningham et al. 2004). An experiment was performed in 1999 to note if a combination of integrated radar methods could be applied to find the discharge of a river without having any of the measuring tools in the water (Powers et al., 1999). The probable accuracy of a stream flow measurement made by current meter has been assessed by evaluating the separate error components (Carter and Anderson, 1963). The aim of this research is to determine discharge of a part of Lesser Zab River using current meter and GPR equipments.

\section{Materials and Methods}

In area- velocity method, the velocity of flow, depth of water and the width of cross-sectional area are measured for a sequence of points along a profile traverses across the river, and the total discharge of the canal is determined by applying the mid-section method, in this method the velocity is determined. In the middle of the strip and the water depth (d) is taken as the mean depth of the strip (Raghunath. 2006), if $b$ is the width, the discharge in the elemental strip is given by:

$\mathrm{Q}=$ Total Discharge $\left(\mathrm{m}^{3} / \mathrm{sec}\right)$

$$
\begin{aligned}
& Q=\sum q_{1}+q_{2}+q_{3}+\cdots+q_{n}=\sum A V \\
& \mathrm{q}=(b d) V_{0.6 d} \text { In shallow water strips } \\
& q=\sum[b d]\left[\left(V 1_{0.2}+V 2_{0.8}\right) / 2\right] \text { In deep water strips }
\end{aligned}
$$

$\mathrm{q}=$ Discharge in each elemental strips.

$\mathrm{V}=$ Velocity $(\mathrm{m} / \mathrm{sec})$

$\mathrm{d}=$ Depth $(\mathrm{m})$

$\mathrm{b}=$ Width (m)

$\mathrm{A}=$ Cross sectional area $\left(\mathrm{m}^{2}\right)$ 


\section{Location of the Study Area}

Klesa area is located to the southeast part of Koya city near Klesa village, Dukan Lake is located $25 \mathrm{Km}$ toward the NE direction, and toward the east there is Taqtaq sub district. The site has a rough topography as it surrounded by hills and mountains especially towards north and northeast (Fig.1).

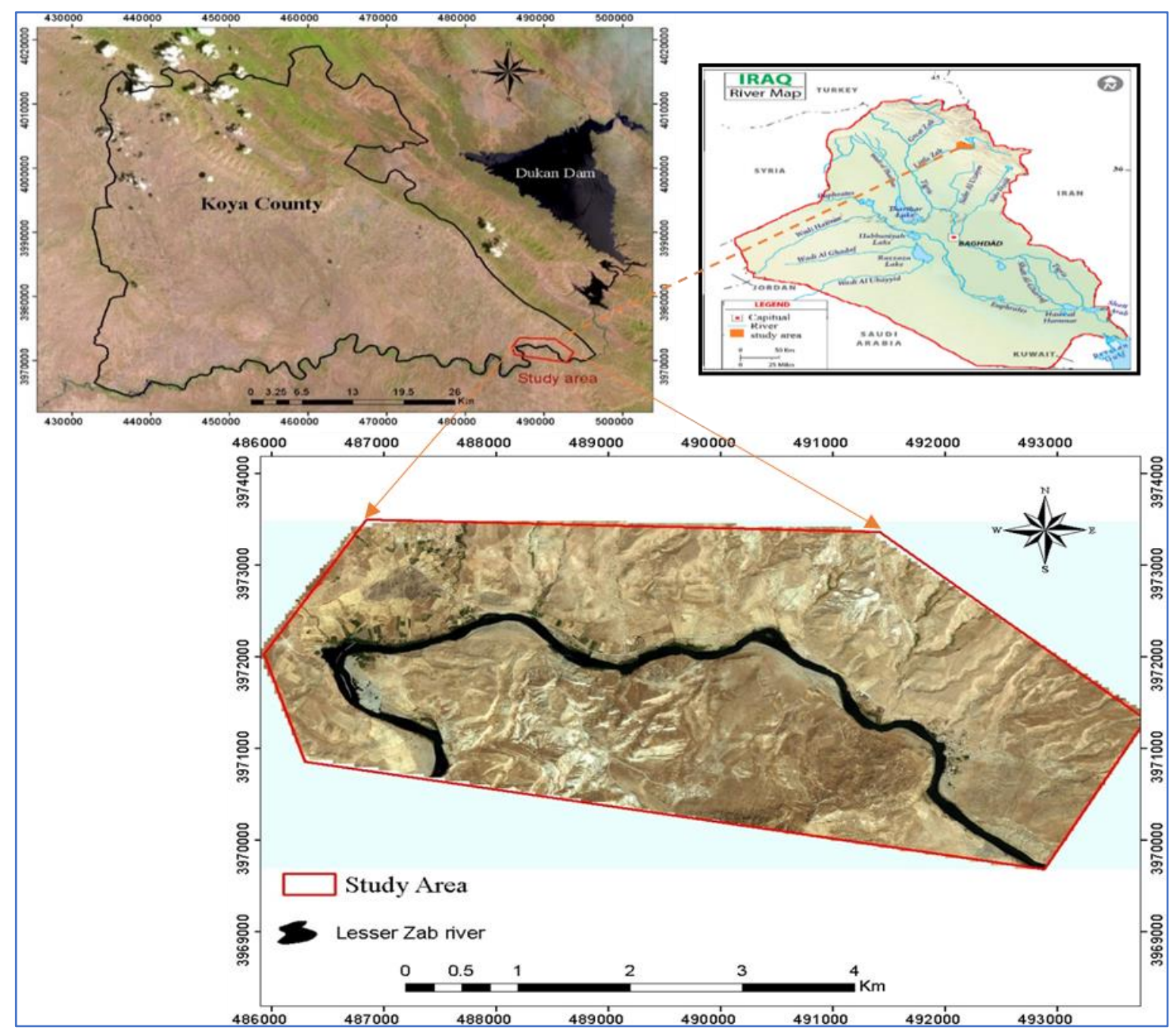

Fig.1. Location map of the study area of the studied area

\section{Experimental Procedure}

- Portable $200 \mathrm{MHz}$ RIS One \& RIS Plus GPR device is used for measuring depth and width of Lesser Zab River (Fig.2).

- Water velocity of Lesser Zab River is measured using water current velocity meter equipment.

- Determining the volumetric flow rate of Lesser Zab River in the studied sites after obtaining results of georadar profiling and water current velocity measurement.

- Data collection.

This part deals with measuring the volumetric flow rate of Lesser Zab River in Klesa area by using mid-section method. In this study mid-section method was used for measuring the discharge of Lesser Zab River. In mid-section method, the section is taken between two vertical lines on which the velocity and depth are measured. The average velocity of water current was calculated by taking the mean value for the measured points velocity along the traverse across the river. Georadar device has been used to determine the depth and the width of the river. 


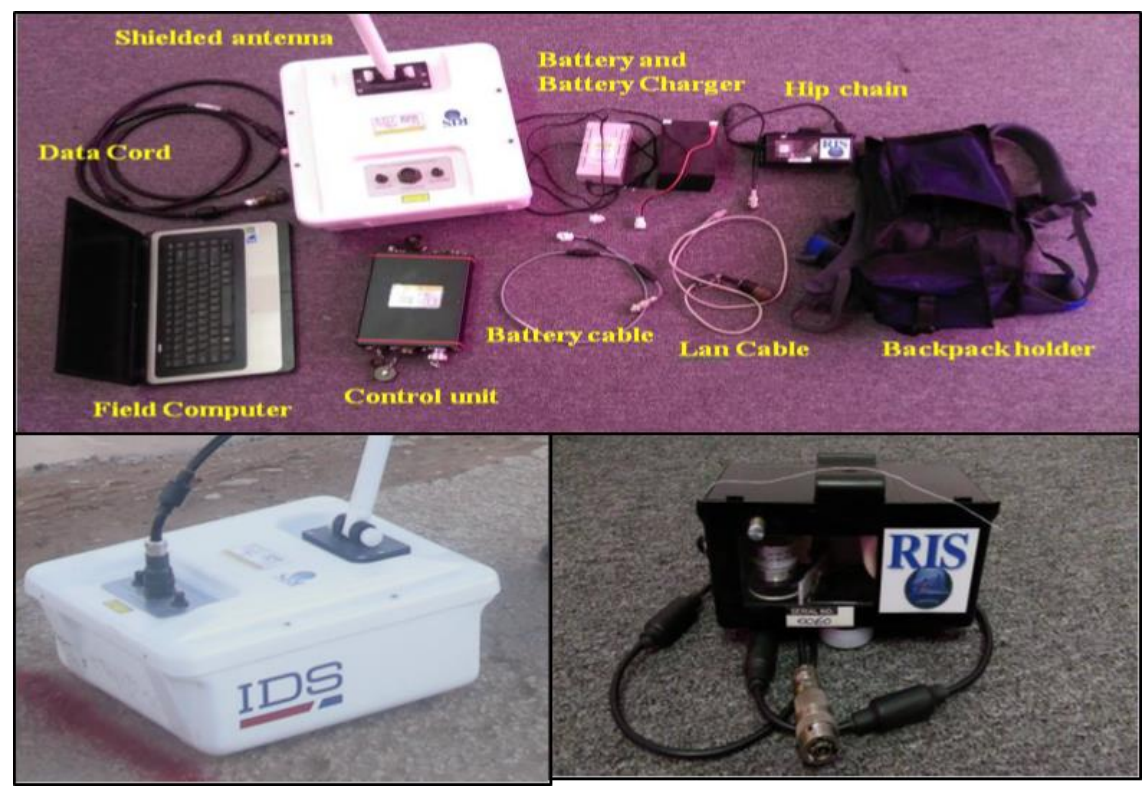

Fig.2. Portable $200 \mathrm{MHz}$ RIS One \& RIS Plus GPR device; A: is the complete georadar unit; B:is the $200 \mathrm{MHz}$ shielded antenna; $\mathrm{C}$ : is the Trigger or distance meter

Current meter device is used to determine the velocity of water, which has been recorded by irrigation directorate in our location (Table 1). The width of the lesser Zab River in Klesa area was divided in to 16 segments. Segment no. 1 and segment no.18 were neglected for measuring depth and velocity because these two parts with very low velocity as they are located adjacently to river banks (Fig.3).

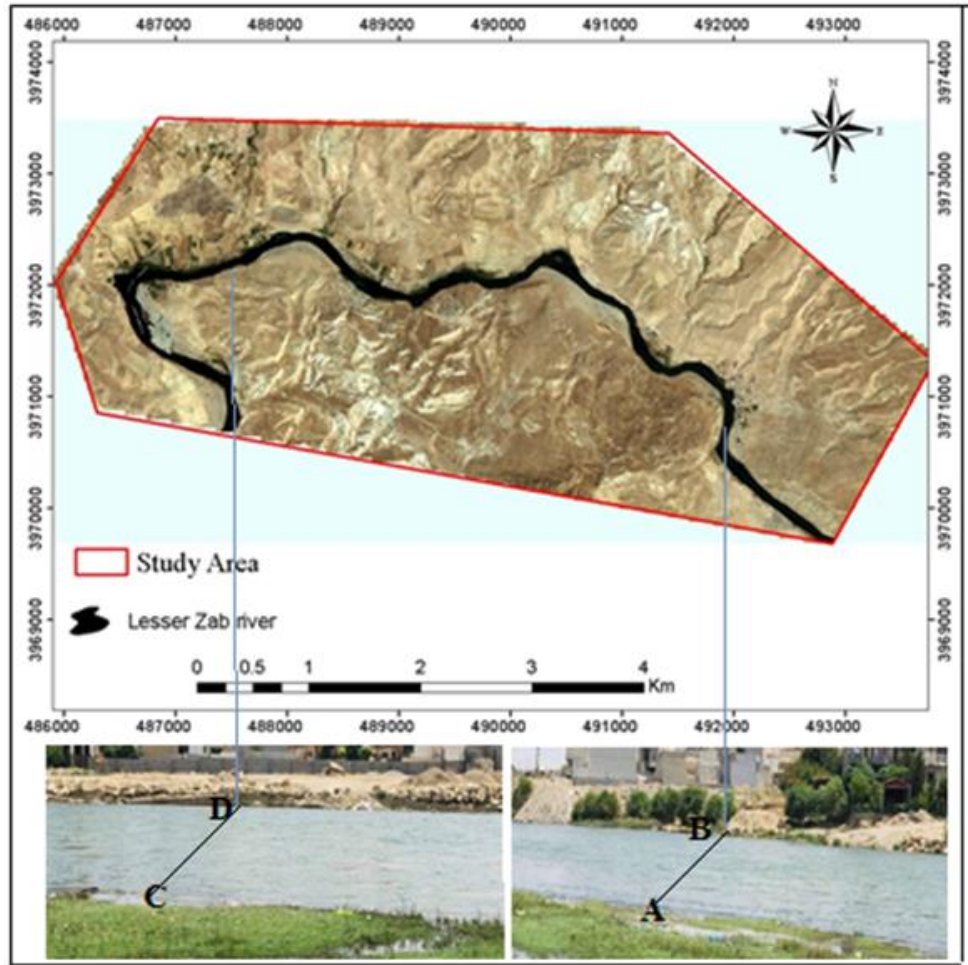

Fig.3. Map shows $\mathrm{AB}$ and $\mathrm{CD}$ section locations. 


\section{Results and Discussions}

The following results were obtained from GPR and water current velocity meter devices measurements:

\subsection{Section (A-B) Results}

- In this section the minimum depth of Lesser Zab River in Klesa area was $1.8 \mathrm{~m}$ and the maximum depth is $4.45 \mathrm{~m}$ as shown in Table 1 and Fig. 4.

- The width of the river in this section is $36 \mathrm{~m}$.

- The minimum velocity in this section is $0.69 \mathrm{~m} / \mathrm{s}$ and the maximum velocity is $1.87 \mathrm{~m} / \mathrm{s}$.

- The maximum discharge was calculated to be $15.12 \mathrm{~m}^{3} / \mathrm{sec}$, and the total discharge was about (136.737) $\mathrm{m}^{3} / \mathrm{s}$.

Table 1. Discharge measurement for the first section

\begin{tabular}{|c|c|c|c|c|c|c|}
\hline Segment & Width (b) & Average & $\begin{array}{l}\text { Water } \\
\text { current } \\
\text { velocity }\end{array}$ & $\begin{array}{l}\text { Water } \\
\text { current } \\
\text { velocity }\end{array}$ & $\begin{array}{c}\text { Average } \\
\text { water } \\
\text { current }\end{array}$ & Discharge \\
\hline No. & (m) & $\begin{array}{c}\text { depth (d) } \\
\text { (m) }\end{array}$ & $\begin{array}{c}\text { at } 0.2 d \\
(\mathrm{~m} / \mathrm{s})\end{array}$ & $\begin{array}{c}\text { at } 0.8 d \\
(\mathrm{~m} / \mathrm{s})\end{array}$ & $\begin{array}{c}\text { velocity }(\mathbf{v}) \\
(\mathbf{m} / \mathbf{s})\end{array}$ & $\begin{array}{c}\mathbf{q}=(\mathbf{d b}) \mathbf{v} \\
\left(\mathbf{m}^{3} / \mathbf{s}\right)\end{array}$ \\
\hline 2 & 2 & 2.2 & 0.65 & 0.73 & 0.69 & 3.036 \\
\hline 3 & 2 & 2.45 & 0.8 & 0.82 & 0.81 & 3.969 \\
\hline 4 & 2 & 2.75 & 0.87 & 0.85 & 0.836 & 4.598 \\
\hline 5 & 2 & 3.1 & 0.88 & 0.79 & 0.835 & 5.177 \\
\hline 6 & 2 & 3.3 & 0.97 & 0.88 & 0.925 & 6.105 \\
\hline 7 & 2 & 3.55 & 1.12 & 0.92 & 1.02 & 7.242 \\
\hline 8 & 2 & 3.8 & 1.22 & 0.98 & 1.1 & 8.36 \\
\hline 9 & 2 & 4 & 1.54 & 1.22 & 1.381 & 11.048 \\
\hline 10 & 2 & 4.3 & 1.72 & 1.55 & 1.635 & 14.061 \\
\hline 11 & 2 & 4.45 & 1.8 & 1.56 & 1.68 & 15.12 \\
\hline 12 & 2 & 4.1 & 1.89 & 1.58 & 1.735 & 14.2271 \\
\hline 13 & 2 & 3.3 & 1.93 & 1.82 & 1.87 & 12.347 \\
\hline 14 & 2 & 2.65 & 1.95 & 1.78 & 1.86 & 9.858 \\
\hline 15 & 2 & 2.3 & 1.82 & 1.75 & 1.78 & 8.188 \\
\hline 16 & 2 & 2.25 & 1.7 & 1.68 & 1.69 & 7.605 \\
\hline 17 & 2 & 1.8 & 1.6 & 1.62 & 1.61 & $\begin{array}{c}5.796 \\
\text { Total } \mathrm{Q}=136 . \\
737 \mathrm{~m}^{3} / \mathrm{s}\end{array}$ \\
\hline
\end{tabular}

\subsection{Section (C-D) Results}

For the second section which is far from the first section for about $5 \mathrm{~km}$ toward the west, the results are as follows:

- The minimum depth in this section was about $1.6 \mathrm{~m}$ and the maximum depth of Lesser Zab River in Klesa area was about $4.75 \mathrm{~m}$ as shown in Table 2 and Fig. 5.

- The width of the river in this area is $36.5 \mathrm{~m}$.

- The minimum velocity for this section is $0.6 \mathrm{~m} / \mathrm{s}$ and the maximum velocity is $1.88 \mathrm{~m} / \mathrm{s}$.

- 4- Maximum discharge is $\mathrm{Q}=147.23 \mathrm{~m} 3 / \mathrm{s}$.

The average discharge for Lesser Zab River in the study area $=141.983 \mathrm{~m}^{3} / \mathrm{s}$. 


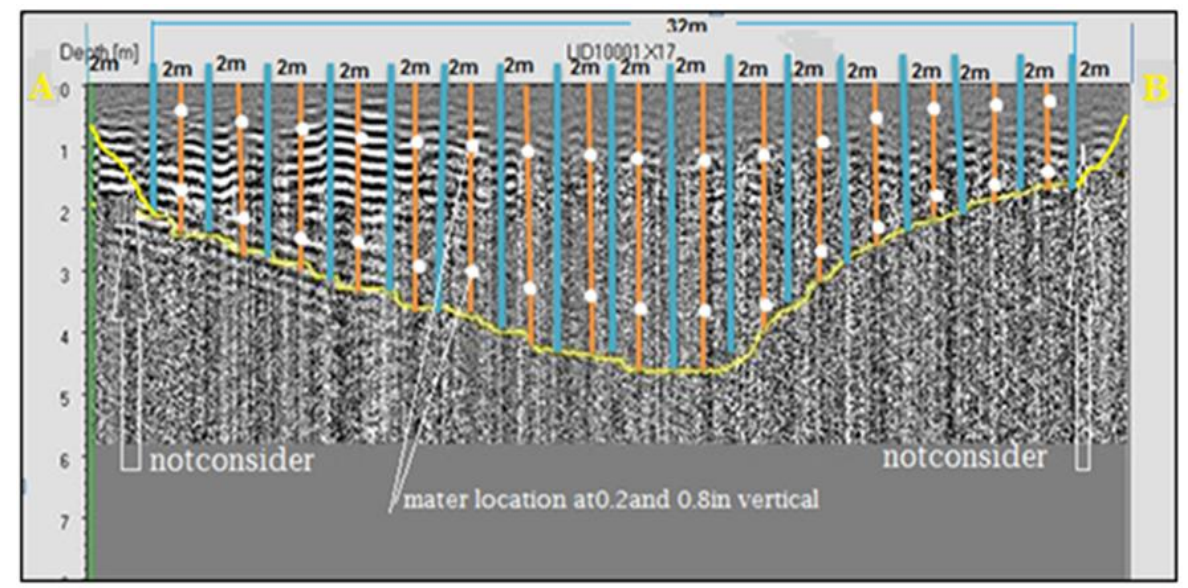

Fig.4. GPR (A-B) section shows maximum depth $(4.45 \mathrm{~m})$ and width $(36 \mathrm{~m})$ measurements

Table 2. Discharge measurement for the second section

\begin{tabular}{|c|c|c|c|c|c|c|}
\hline Segment & Width (b) & Average & $\begin{array}{c}\text { Water } \\
\text { current } \\
\text { Velocity }\end{array}$ & $\begin{array}{c}\text { Water } \\
\text { current } \\
\text { Velocity }\end{array}$ & $\begin{array}{l}\text { Average } \\
\text { water } \\
\text { current }\end{array}$ & Discharge \\
\hline No. & (m) & $\begin{array}{c}\operatorname{depth}(d) \\
(\mathrm{m})\end{array}$ & $\begin{array}{c}\text { at } 0.2 \mathrm{~d} \\
(\mathrm{~m} / \mathrm{s})\end{array}$ & $\begin{array}{c}\text { at } 0.8 d \\
(\mathrm{~m} / \mathrm{s})\end{array}$ & $\begin{array}{c}\text { velocity }(\mathbf{v}) \\
(\mathrm{m} / \mathbf{s})\end{array}$ & $\begin{array}{c}q=(d b) v \\
\left(m^{3} / s\right)\end{array}$ \\
\hline 2 & 2 & 1.6 & 0.55 & 0.69 & 0.62 & 1.98 \\
\hline 3 & 2 & 2.15 & 0.7 & 0.78 & 0.74 & 3.18 \\
\hline 4 & 2 & 2.8 & 0.84 & 0.88 & 0.6 & 3.36 \\
\hline 5 & 2 & 3.45 & 0.88 & 0.81 & 0.84 & 5.79 \\
\hline 6 & 2 & 3.75 & 0.93 & 0.87 & 0.9 & 6.75 \\
\hline 7 & 2 & 4.05 & 1.15 & 0.93 & 1.04 & 8.42 \\
\hline 8 & 2 & 4.3 & 1.28 & 0.94 & 1.11 & 9.54 \\
\hline 9 & 2 & 4.6 & 1.64 & 1.42 & 1.53 & 14.07 \\
\hline 10 & 2 & 4.75 & 1.82 & 1.6 & 1.71 & 16.24 \\
\hline 11 & 2 & 4.25 & 1.83 & 1.58 & 1.7 & 14.45 \\
\hline 12 & 2 & 3.75 & 1.89 & 1.56 & 1.72 & 12.9 \\
\hline 13 & 2 & 3.55 & 1.91 & 1.86 & 1.88 & 13.34 \\
\hline 14 & 2 & 3.2 & 1.93 & 1.8 & 1.86 & 11.9 \\
\hline 15 & 2 & 2.9 & 1.75 & 1.73 & 1.74 & 10.09 \\
\hline 16 & 2 & 2.6 & 1.68 & 1.64 & 1.66 & 8.63 \\
\hline \multirow[t]{3}{*}{17} & 2 & 2.1 & 1.55 & 1.6 & 1.57 & 6.59 \\
\hline & & & & & & Total \\
\hline & & & & & & $\mathrm{Q}=147.23 \mathrm{~m}^{3} / \mathrm{s}$ \\
\hline
\end{tabular}

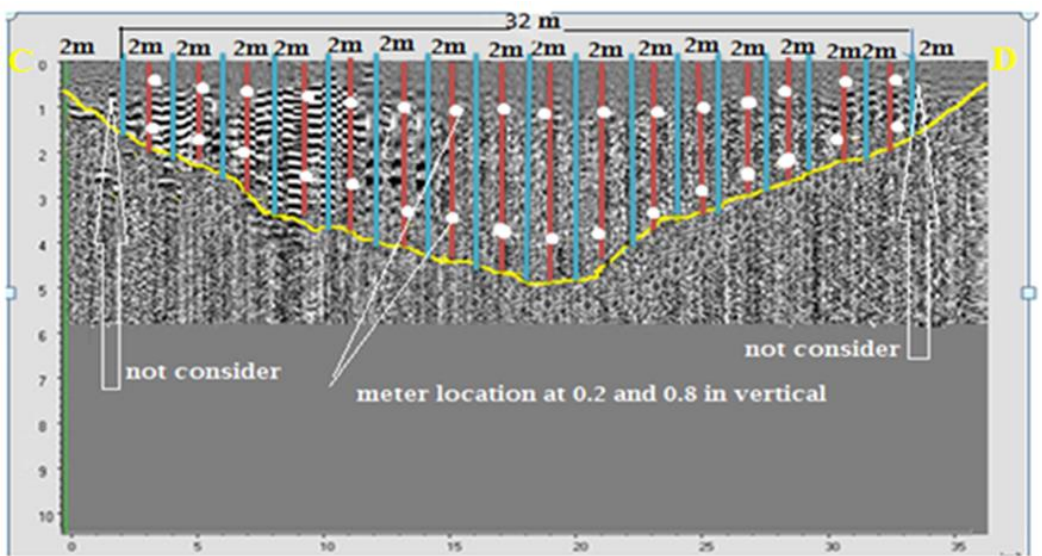

Fig.5. GPR (C-D) section shows maximum depth $(4.75 \mathrm{~m})$ and width $(36.5 \mathrm{~m})$ measurements 


\section{Conclusions}

The main conclusions of the current study could be summarized as follows:

- The results indicated that the maximum width of the river at the section A-B was about $36.5 \mathrm{~m}$.

- The maximum river floor average depth of Lesser Zab River in the study area was about $4.75 \mathrm{~m}$.

- The Maximum velocity of the river at the section C-D was about $1.88 \mathrm{~m} / \mathrm{s}$.

- The water flow rate deviate from $136.737 \mathrm{~m}^{3} / \mathrm{s}$ to $147.23 \mathrm{~m}^{3} / \mathrm{s}$. The average discharge for Lesser Zab River $=141.983 \mathrm{~m}^{3} / \mathrm{s}$. this value is under normal average because the data was taken during November 2019, when the water quantity released from Dokan reservoir is minimum in November, Because of the mild weather and the lack of electricity consumption, so using this results in water resource management and planning for satisfying domestic consumption, irrigation, industrial consumption in Koya city will be economically beneficial for the water management policy.

\section{Acknowledgements}

The authors highly appreciated the faculty of engineering, Koya university. The authors are very grateful to the reviewers, Editor in Chief Prof. Dr. Salih M. Awadh, the Secretary of Journal Mr. Samir R. Hijab, and the Technical Editors for their great efforts and valuable comments.

\section{References}

Amran, T., Ismail, M., Ismail, M., Amin, M., Ahmad, M. and Basri, N. 2017. GPR application on construction foundation study, IOP Conf. Series: Materials Science and Engineering. 271, 012089.

Aziz, S., Slewa, E., Abdula, W., 2017. Evaluation of water quality for Lesser-Zab River for various application. Kirkuk University Journal-Scientific Studies, 12 (4), 209-231.

Bakir, H., Thabit, J., 2016. In situ measuring of relative dielectric permittivity to calculate electromagnetic wave velocity, Iraqi Journal of Science, Baghdad University, 56 (3C), 2252-2257.

Bapeer, G., Bakir, H., 2018. Applying ground penetrating radar current meter devices for measuring Lesser Zab River Discharge in Taqtaq Area, Iraq. (IICETA), Al-Najaf, 151-154.

Carter, R.W., Anderson, I. E., 1963: Accuracy of current meter measurements, Journal of the Hydraulics Division, 89 (4), 105-115.

Chauhan, M., Kumar, V., Dikshit, P., and Dwivedi, S., 2014. Comparison of discharge data using ADCP and current meter. International Journal of Advances in Earth Sciences, 3 (2), 81-86.

Cunningham, K. J., Carlson, J. L., Wingard, G. L., Robinson, E., and Wacker, M. A. 2004. Characterization of quifer heterogeneity using cyclostratigraphy and geophysical methods in the Upper Part of the Karstic Biscayne Aquifer, Southeastern Florida, U.S. Geological Survey Water-Resources Investigations Report 03-4208, 66.

Daniels, J.J., Brower, J., and Baumgartner, F. 1998. High resolution GPR at Brookhaven National Laboratory to delineate complex subsurface targets: Journal of Environmental and Engineering Geophysics, 3 (1), 1-5.

David, L., Jeffrey, C., Stephen E., Arthur A., and Robert J., 1997. Mineral Resources Program, U.S. Geological Survey Tests of Ground-Penetrating Radar and Induced Polarization for Mapping Fluvial Mine Tailin on the Floor of the Couer d'Alene River, Idaho. SAGEEP symposium, Reno, Nevada.

Harpold, A., Mostaghimi, S., Vlachos, P., Brannan, K., Dillaha, T., 2006. Stream discharge measurement using a large-scale particle image velocimetry prototype (electronic resource). American Society of Agricultural and Biological Engineers. 49(6), 1791-1805.

Kassim, T., Sabri, A., Salman, M. 2007. The limnological effects of River Lesser-Zab on Tigris River, Iraq. Baghdad Science Journal, 4 (3), 452-457.

Lachhab A., Booterbaugh, A. and Beren M. 2015. Bathymetry and sediment accumulation of Walker Lake, using two GPR antennas in a new integrated method. Journal of Environmental and Engineering Geophysics. 20 (3), 245-255.

Powers, C.J., Haeni, F.P., and Smith, S., 1999. Integrated use of continuous seismic-reflection profiling and ground-penetrating radar methods at John's Pond, Cape Cod, Massachusetts. Proceedings of the 
Symposium on the Application of Geophysics to Engineering and Environmental Problems, Oakland, California, 359-368

Raghunath, H.M., 2006. Hydrology principles, analysis, and design, 2nd Ed. New Age International Publishers. Sadeq, S., Alhamdany,T., 2021. Geometric study of the Lesser Zab River channel between Altun-Kupri City and Dibbs Dam, Kirkuk, NorthernIraq, Iraqi Geological journal, 54(1F), 33-43.

Subramanya, K. 2008.Engineering Hydrology. 3rd Ed., chapter 6, Tata Mc Graw -Hill Publishing Company limited New Delhi.

Tazioli, A. 2011. Experimental methods for river discharge measurements: comparison among tracers and current meter. Hydrology Science Journal, 56(7), 1314-1324.

Termite, L., Todisco, F., Vergni, L., Mannocchi, L. 2013. A neuro-fuzzy model to predict the inflow to the guardialfiera multipurpose dam (Southern Italy) at medium-long time scales. Journal of Agricultural Engineering. Volume XLIV(2S), E158. 